\title{
The Return to Direct Investment in Private Firms: New Evidence on the Private Equity Premium Puzzle*
}

\author{
Kasper Meisner Nielsen \\ Hong Kong University of Science and Technology, Clear Water Bay, Hong Kong \\ E-mail:nielsen@ust.hk
}

\begin{abstract}
This paper uses a novel dataset to analyze the return to direct investments in private firms by pension funds. We have two key findings. First, direct investments in private firms have underperformed public equity by 392 basis points per annum under conservative risk adjustments. Second, initial mispricing, due to overoptimism or misperceived risk, and subsequent low capital gains seem to explain the gap in returns to private firms. Overall, these findings complement the finding of Moskowitz and Vissing-Jørgensen (2002) of low returns on entrepreneurial investments and provide new insight into the existence of what they call the private equity premium puzzle: Even professional investors with well-diversified portfolios
\end{abstract}

\footnotetext{
*I am grateful to an anonymous referee, Morten Bennedsen, David Brophy, Robert Chirinko, David J. Denis, Miguel Ferreira, Jana Fidrmuc, Denis Gromb, Hans Christian Kongsted, Nikolaj Malchow-Møller, Ludovic Phalippou, Thomas Rønde, Carsten Sørensen, Annette Vissing-Jørgensen, Daniel Wolfenzon, and seminar participants at Bocconi University, Cass Business School, Chinese University of Hong Kong, Copenhagen Business School, Durham Business School, Imperial College, Instituto de Empresa, ISCTE Business School, Lund University, Manchester Business School, Tilburg University, University of Copenhagen, the Financial Intermediation Research Society's Conference in Shanghai 2006, the FMA 2006 Meeting in Salt Lake City, the Netspar 2007 Conference in Amsterdam, the Asian FMA 2007 Meeting in Hong Kong, the NTU International Conference on Economics, Finance, and Accounting in Taipei 2008, the Institutional Investors and Asset Management Industry Conference at University of Oregon 2008, and the 2010 EFM Symposium on Entrepreneurial Finance and Venture Capital Markets in Montreal for helpful comments and suggestions. This project has been supported financially by the Centre for Economic and Business Research (CEBR), the Danish Centre for Accounting and Finance (D-CAF), and the Economic Policy Research Network.

Contact information: Department of Finance, Hong Kong University of Science and Technology, Clear Water Bay, Hong Kong SAR, China. E-mail: nielsen@ust.hk
} 
like pension funds seem to get a poor risk-return tradeoff from investing directly in private firms.

Keywords: private equity; pension funds; direct investments, private firms

JEL classifications: $G 23, G 24$

\section{Introduction}

Asset pricing and investment theory have long studied the risk and return characteristics of public equity. As pointed out by Moskowitz and Vissing-Jørgensen (2002), the private equity market is as important as the public equity market in terms of size and growth. Despite this finding, little is known about the risk-return tradeoff in private equity investments.

A few recent papers have provided insights on the return to private equity funds. Although private equity funds have high relative performance gross of fees (Cochrane (2005); Korteweg and Sørensen (forthcoming)), the relative performance net of fees appears low (Kaplan and Schoar (2005); Phalippou and Gottschalg (2009)). This result suggests that the total rent captured by private equity funds is probably excessive, and raises questions about why investors allocate large amounts to this asset class given its historically poor performance.

This paper adds to this line of work by considering an alternative way to obtain exposure to private equity: through direct investments in private firms. The driving force for direct investments lies in the opportunity to make private equity-like returns without having to pay high management fees: typically, a one to two percent management fee and 20 percent of returns. High fees have already motivated pension funds in Canada to establish direct investment programs. For instance, the largest Canadian pension fund CDP Capital has made more than 500 direct investments in private firms to date. From the existing literature we know relatively little about the scope and merits of this alternative strategy. ${ }^{1}$ This is primarily because of difficulties in obtaining data, as noted by Fenn, Liang, and Prowse (1995), but partly because prior literature implicitly assumes that direct investments in private firms do not occur today - at least not in the United States, where the private equity market is highly developed. However, institutional investors appear to invest directly in private firms in most developed countries. Evidence from surveys of pension funds' portfolio allocations reveals that direct investments are common in Australia, Canada, Denmark, and the Netherlands (Cumming and Johan (2007), and Nielsen (forthcoming)), and recent coverage in the business media reports evidence of significant direct investment by some of the largest institutional investors in Germany, Switzerland, Turkey, United Kingdom, and the United States. ${ }^{2}$ In addition,

\footnotetext{
${ }^{1}$ There are few studies of direct investments in private firms. The main exception is Nielsen (2008), who shows that institutional investors mitigate the risk of minority expropriation by investing in private firms with good governance mechanisms, and Nielsen (forthcoming) who shows that direct investments by pension funds are common in Australia, Canada, Denmark and the Netherlands.

${ }^{2}$ See Financial Times, November 7, 2005, "Pension Funds Bypass Private Equity Houses": FT Mandate, February 2006 Issue, "Boost for Private Route"; and the New York Times, October 8, 2006, “A New Pension Game.”
} 
there is substantial anecdotal evidence showing that public pension funds in the United States (at least historically) have invested substantial funds directly in private firms. ${ }^{3}$ Fenn, Liang and Prowse (1995), for instance, estimate that around 20 percent of U.S. institutional investments in private equity were direct investments in the 1990s. Although this alternative investment channel appears to be quite common, we know relatively little about it. This paper attempts to fill the gap by focusing on pension funds, which are known to be the largest contributor to private equity funds (Gompers and Lerner (2000)).

Our objective of examining the return to pension funds' direct investments in private firms poses a significant challenge as data are generally not available. Pension funds rarely provide detailed insights into the return within asset classes, and in most countries, private firms are not required to provide information to the general public. This paper rises to this challenge by exploiting unique data on Danish pension funds' direct investments in private firms. The advantage of this dataset is twofold. First, the Danish Financial Statement Act has, since 1995, obliged Danish pension funds to disclose the returns on asset classes. This creates a novel opportunity to estimate the net return to direct investments in private firms. We find a large negative and statistically significant abnormal return to private equity. Our most conservative riskadjusted estimate shows that direct investments have underperformed by 392 basis points per annum. This economically and statistically significant underperformance suggests that direct investment in private equity is a poor investment alternative. Moreover, this result complements the finding of Moskowitz and Vissing-Jørgensen (2002) of low returns on entrepreneurial investments and provides new insight into the existence of what they call the private equity premium puzzle. Our results show that pension funds with well-diversified portfolios also seem to accept a poor risk-return trade-off when investing in private equity.

Second, the novelty of our data allows us to examine potential explanations to this puzzle. The existing literature has listed high-risk tolerance; preference for risk; pecuniary or non-pecuniary benefits; over-optimism; misperceived risk; and politically motivated preferences as possible explanations for why investors choose private equity. Whereas these potential explanations have been discussed in the literature, they have not, to our knowledge, been subject to rigorous scrutiny. This paper fills this gap. From pension funds' annual reports, we identify their portfolios of privately held firms. We

\footnotetext{
${ }^{3}$ To validate this claim, I searched LexisNexis for newspaper articles on direct investments by pension funds in the United States: CalPers have historically allocated about 2 percent of their assets ( $\$ 1.6$ billion) directly into private firms, although their current strategy relies on funds. TIAARCE has historically managed a direct investment program of similar magnitude. State Retirement Systems and Public Pension Funds in Alabama, California, Connecticut, Georgia, Kansas, New Jersey, New York, Missouri, Pennsylvania, Rhodes Island, and Virginia, among others, have all promoted in-state investment programs varying in size from 2 to 5 percent of total investment assets, or three-digit million dollar figures. These programs allocate investments to private firms within the state. Similarly, State Pension Funds in Oregon and Washington manage significant co-investment programs that invest directly in private firms alongside a private equity fund. In addition, a recent report by Technology Alliance (2007) provides an excellent catalogue of current state programs for venture capital investments. Currently, at least a handful of states have programs through which they take direct equity positions in private companies. Interestingly, these direct investment programs have received negative press in the past due to some high-profile failures, which have resulted in at least one state, Kansas, prohibiting direct investments.
} 
link these to a unique dataset that comprises all privately held firms in Denmark. We thereby obtain data that allow us to test potential explanations to the puzzle.

Our analysis of potential explanations begins by excluding the possibility that pension funds have a high-risk tolerance, as prior research has documented that pension funds are prudent investors (Del Guercio (1996); Gompers and Metrick (2001)). Further, we find no evidence to suggest that pension fund investments in private firms have been driven by self-interested managers, as managers are rarely appointed to the boards of portfolio companies. We thereby reject, using a very direct measure, the theory that pension fund investments to any great extent are driven by pecuniary or non-pecuniary benefits accruing to fund managers. We also reject anecdotal evidence suggesting that investments are politically motivated by showing that having a politically influenced board has no effect on the returns. Finally, we distinguish whether the poor return is caused by poor economic performance or by low capital gains. We find that the portfolio companies' earnings performance is identical to a matched sample of non-portfolio companies. Thus, the poor return must be caused by low capital gains. This finding points to initial mispricing, resulting from over-optimism or misperceived risk, as the likely explanation for the poor risk-return tradeoff.

Overall, our findings suggest that the private equity premium puzzle also extends to professional investors with well-diversified portfolios like pension funds. Although it is entirely possible that these findings are specific to pension funds in Denmark, the results seem consistent with anecdotal evidence from other countries. ${ }^{4}$ Given the apparent cross-country prevalence of direct investments, it is worthwhile to understand whether the private equity premium puzzle extends to professional investors as well. In that respect, this paper exploits novel data to provide an out-of-sample test that allow us to gain new evidence on the private equity premium puzzle.

This paper proceeds as follows: In the next section we survey the literature that estimates the return to investments in private firms. Section 3 describes the data. Section 4 analyzes the risk-return tradeoff of the pension funds' investments in private firms. In Section 5, we scrutinize potential sources of the poor return and provide new insight into the private equity premium puzzle. Section 6 offers some concluding remarks.

\section{Prior Literature on the Return to Investments in Private Firms}

The literature estimating the return to investments in private firms has primarily employed two sources of data. One has used surveys of households and consumer finance, whereas the other has used data on private equity funds from specialized agencies, such as Venture Economics. As a result, the first approach estimates the return to investments by entrepreneurs, whereas the second estimates the return to investments by equity funds with an active management role.

Using survey data on U.S. individuals, Hamilton (2000) compares the wage differential between self-employed and paid employees. He finds that the self-employed earn a significantly smaller stream of future earnings. This finding suggests that entrepreneurs

\footnotetext{
${ }^{4}$ Lerner, Schoar, and Wongsunwai (2007), for instance, cite casual evidence of direct investments being abandoned by pension funds in the United States as a result of poor performance. A more concrete example is provided in Nielsen (forthcoming) who details the decision by policymakers in Kansas to ban direct investments as a result of poor historic performance.
} 
are willing to sacrifice substantial earnings in exchange for non-pecuniary benefits, such as the value of "being your own boss." In a related study, Moskowitz and VissingJørgensen (2002) estimate the return on investments in privately held firms by U.S. households. They find that the return to private firms is no higher than the return to public equity and that entrepreneurial investments are extremely concentrated and poorly diversified. This finding has initiated awareness of the private equity premium puzzle: why do households willingly invest substantial amounts in assets with such a poor riskreturn trade-off? The private equity premium puzzle suggests that entrepreneurs receive large non-pecuniary benefits from the ownership of privately held firms; otherwise, they should invest in the public equity market.

The initial studies of private equity funds have used data on publicly traded venture capital funds to estimate returns (see survey by Denis (2004)). Martin and Petty (1983) provide evidence of a positive excess return to private equity, using a small sample of publicly traded venture funds in the United States, whereas Gompers and Lerner (1997) find evidence of positive excess return for a single publicly traded venture capital group. Using data on the performance of individual venture capital investments, a number of studies have attempted to build a private equity index (Peng (2001), Quigley and Woodward (2003), Woodward and Hall (2003)) or to estimate the return on individual venture capital projects (Cochrane (2005)). As Kaplan and Schoar (2005) point out, these studies are plagued by sample selection bias, as the return can be observed only if there is some sort of transaction involving the investment. To circumvent this potential problem, other studies have focused on the cash-flow stream between private equity funds and their limited partners. Using a large sample of private equity funds between 1970 and 2001, Kaplan and Schoar (2005) find that the return, net of fees, does not exceed the return on public equity. Similarly, Jones and Rhodes-Kropf (2003) examine the effect of idiosyncratic risk on the pricing of private equity investments and find no excess return even though the average fund alpha is positive (but small).

In a recent paper, Phalippou and Gottschalg (2009) suggest that the performance results in Kaplan and Schoar (2005) are significantly biased toward winners. Adjusting for sample selection and writing off the residual value of "living dead" funds, Phalippou and Gottschalg (2009) find significant underperformance for private equity funds. Assuming that the residual value of these funds' investments is equal to half of that reported is sufficient to reach the conclusion that private equity funds, on average, have underperformed the Standard \& Poor's 500 index by as much as 3.3 percentage points per annum.

Ljungqvist and Richardson (2003) argue that prior studies do not take into account the timing of the contributions to the funds and the risk profile of the portfolio companies. Using data from a large anonymous institutional investor, they find that it takes 6 years for funds to invest more than 90 percent of committed capital, and 8 years before the internal rate of return becomes positive. Taking these measurement problems into account, Ljungqvist and Richardson (2003) find evidence of a positive risk-adjusted return to private equity investments. While this finding contrasts with the results of the prior literature, their study suffers from a relatively modest sample size. The limited sample size is of particular concern if there is persistence in fund performance over time (Kaplan and Schoar (2005); Phalippou and Gottschalg (2009)) or large heterogeneity in the performance of investor classes (Lerner, Schoar, and Wongsunwai (2007)).

Finally, Cumming and Waltz (2010) document significant systematic biases in the voluntary reporting of fund performance; they find that these biases depend on the degree of accounting conservatism and the strength of the legal environment in a country. 
This finding raises concern about the use of data that are voluntarily reported by private equity funds in the absence of mandatory reporting and disclosure rules.

A survey of the literature highlights three major empirical challenges: first, sample selection bias is introduced as a result of the fact that accurate returns are observable only when an exit takes place. Second, as survey and fund level data rarely give access to actual cash flows, it is difficult to account for the timing of investments and the accuracy of reported returns. Third, returns are confounded by management and advisory roles of investors. The survey also highlights the existence of an apparent private equity premium puzzle: why do investors seemingly accept the poor risk-return tradeoff offered by private equity?

This paper seeks to uncover new evidence relating to this puzzle by scrutinizing its potential explanations. Moreover, as prior literature has focused (for data reasons) on entrepreneurial investments and private equity funds, the current paper provides the first estimate of the return to investments in private firms by investors without an active management role. In addition, this study uses a new data source that is likely to be less exposed to the measurement and data problems of prior studies: The use of data from surveys of households could create a negative bias with regard to the estimated return, since consumption within the firm is likely to be unreported. Similarly, data on private equity funds can suffer from survivorship bias, sample selection problems, and backfilling. Returns to pension funds' investments are reported and externally audited according to government guidelines in the Financial Statement Act, which induces fairly coherent reporting practices across funds and prevents backfilling. Finally, our data include detailed holdings information, which allows us to risk-adjust the returns rather than assuming a market model with a beta equal to one (Moskowitz and VissingJørgensen (2002); Kaplan and Schoar (2005); Lerner, Schoar, and Wongsunwai (2007), among others). Thus, a major contribution of this paper is to provide out-of-sample evidence of the existence of a general private equity premium puzzle using data that are less plagued by the empirical challenges faced by prior literature.

One immediate limitation to the interpretation of our results is that they might be sample specific, as Lerner, Schoar, and Wongsunwai (2007) have documented large heterogeneity in the performance of investor classes. Thus, although we present additional evidence consistent with the existence of a (general) private equity premium puzzle, our analysis is insufficient to conclude that private equity as an asset class is dominated by other asset classes. Despite this limitation, the paper does provide complementary evidence for the existence of a private equity premium puzzle. In particular, the paper provides the first estimate of the return to investors in private firms who are without an active management role. Moreover, the novelty of the data provides an opportunity to perform an out-of-sample test of the disappointing return to private equity documented in prior literature.

\section{Data on Pension Funds' Investment in Private Firms}

\subsection{Data collection}

The Danish Financial Statements Act has, since its enactment in 1995, obliged Danish pension funds to state their portfolio return on individual asset classes. The act specifies six categories of assets: real estate, subsidiaries, equity, bonds, loans, and other; it also further partitions equity into public and private, and firms into domestic and foreign, 
subcategories. For each asset class (as well as for subcategories) pension funds must report the market value of the allocation to the asset class (primo and ultimo) as well as the return on the asset class. The act further specifies that the yearly return, $\mathrm{r}_{\mathrm{T}}$, should be calculated using a time- and value-weighted formula:

$$
r_{T}=\prod_{t=1}^{T}\left(1+r_{t}\right)-1
$$

where $\mathrm{r}_{\mathrm{t}}$ is the value-weighted return in sub-period $t$ within year $T$, is given by

$$
r_{t}=\frac{N A V_{i}-N A V_{t-1}+C F_{t-1, t}}{N A V_{t-1}-W C F_{t-1, t}}
$$

and $\mathrm{NAV}_{\mathrm{t}}$ and $\mathrm{NAV}_{\mathrm{t}-1}$ are the net asset value (market value) of the asset class at time $t$ and $t-1$, respectively. $\mathrm{CF}_{\mathrm{t}-1, \mathrm{t}}$ is net cash flow within sub-period $\mathrm{t}$, and $\mathrm{W}$ is the relative number of days each cash flow has been included in the portfolio. If multiple cash flows occur within the period, each cash flow is weighted with its own relative weight. The length of each time-period is, in principle, determined by flows into and out of the portfolio of the particular asset. However, it is customary among pension funds to use monthly sub-periods. The reported returns, therefore, are not biased by new investments within the year and are comparable across time and asset classes.

From exhibits in the pension funds' annual reports, we manually collect information about each pension funds' investment portfolio and the return on these investments for each year from 1995 to $2004 .^{5}$ Returns to investments in private firms are reported on an annual basis by the pension fund according to the method specified in Equation (1) and (2). All numbers are reported at the portfolio level, and thus, returns are aggregate.

In addition, the act obliges pension funds to provide a list in their annual reports of any investments in firms where either their cash flow or voting stake exceed 5 percent. Given that ownership of privately held firms is extremely concentrated, this list is likely to include all portfolio investments that have generated the returns We link this data to the population of privately held corporations in Denmark. These data are from the firms' filing of annual account statements with the Danish Ministry of Economic and Business Affairs, which all limited liability companies in Denmark are obliged to do by law. These data includes items from income statements and balance sheets as well as the identities of the CEOs and board members. These detailed data enable us to investigate the sources of the returns to private firms.

\subsection{Assessment of market value of private firms}

An essential part of understanding the performance of private firms relates to the use of market valuations in the reported return. Whereas market values for publicly held firms are easily observed, the "market" values of privately held firms are only observable when there is some sort of "exit". 6 Thus, if no exit occurs, the market value is the pension

\footnotetext{
${ }^{5}$ Throughout this paper we only use domestic investments and refer to them as public and private firms. We have chosen to exclude foreign private equity investments, since these firms are not included in our firm-level dataset. Furthermore, most foreign private equity investments by Danish pension funds took place toward the very end of the sample period.

${ }^{6}$ In the event that a privately held firm goes public, the IPO price will be recorded as the exit price for the investment in private firms, and as the entry price for the "new" public equity
} 


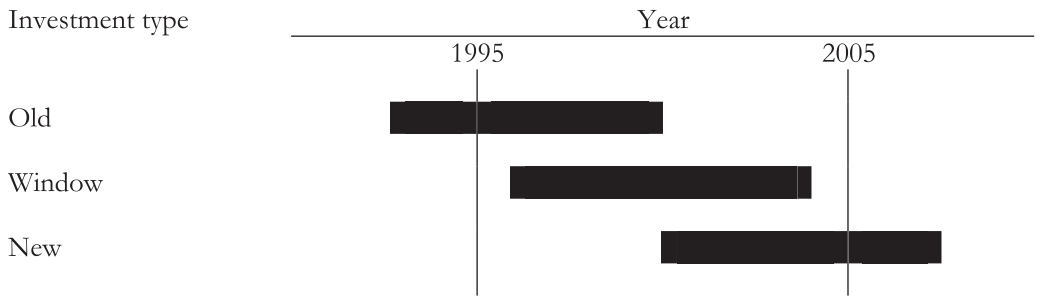

Figure 1. Illustration of window approach to evaluating portfolio return to private firms.

This figure classifies portfolio investments into three types: Old, Window, and New investments. Old investments are undertaken pre-window and un-exited before 1995. Window investments are undertaken and exited within the return window. New investments are undertaken within the window and un-exited ultimo 2004.

funds' estimate of net asset value (NAV). Although the Financial Statement Act requires NAVs to be adjustment whenever changes are "permanent", there is still substantial discretion left to pension fund managers. If pension fund managers are conservative in their assessment of NAVs, this introduces a potential bias to the reported return. The observed returns to private firms are, therefore, a mix of current and stale returns, which is a problem shared with the prior literature. ${ }^{7}$ Most of the pre-existing studies attempt to overcome this problem by evaluating the return to mature investments, as valuations are typically conservative in early years. One drawback of this approach is that one might introduce sample selection bias if unsuccessful investments disappear from the sample or, alternatively, overestimate the return, if funds, as documented by Phalippou and Gottschalg (2009), do not adjust the market value of living deads.

Our data allow us to use a portfolio approach, as the reported returns cover a ten-year window of portfolio returns. The benefit of this approach is that the potential bias from conservative valuations is likely to be limited as the portfolio at any given time will consist of a mix of old and new investments. Figure 1 provides a simple illustration of this effect, focusing on three underlying types of investments during the period from 1995 to 2005; "Old" investments undertaken and unexited before 1995; "Window" investments undertaken and exited within the period; and "New" investments undertaken between 1995 and 2004 and unexited ultimo 2004. If pension funds are conservative in their valuation, the average reported returns within the period will be: positively biased for old investments; unbiased for window investments; and negatively biased for new investments. However, as the observed period from 1995 to 2004 covers both old and new investments, it follows that conservativeness can only bias the average portfolio return if either the investments in private firms increased significantly over the return

investment. Thus, any gain from going public will rightfully count as a private equity return. In any case the impact of IPOs on the results is limited due to very few IPOs in the sample period.

${ }^{7}$ Gompers and Lerner (2001) underscore that venture capitalists often refrain from marking portfolio company values to market to present a conservative assessment of the portfolio valuation. Similarly, Woodward (2004, p. 11) emphasizes that the return to venture capital funds are a mix of current and stale returns; Each quarter, the general partners in the VC fund report the value of each company in which the fund invests to the limited partners. These values are nearly always based on each company's most recent round of financing. 
window (i.e., the market value of new is significantly larger than for old investments), or pension funds became more conservative during the period (i.e., negative bias for new investments is numerically larger than the positive bias resulting from old investments). Moreover, as the length of the return evaluation period increases, the ratio of unbiased window investments to total investment increases, thereby reducing the potential bias from the two sources mentioned above.

A priori, there is no reason to suspect that pension funds should have become more conservative during the evaluation period. It follows from the argument above, therefore, that the average portfolio return will be unbiased if pension funds did not drastically increase their investments in private firms toward the end of the window. Thus, by examining the development of the portfolio and the reported returns, we can ascertain that the results are not an artifact of conservative valuations without introducing potential selection bias to the evaluation of returns.

\subsection{Descriptive statistics}

Table 1 shows descriptive statistics on the number and the size of pension funds in Denmark from 1995 to 2004. Market values of assets are indexed to 2000 Danish kroner. The population of pension funds in Denmark in the sample period has consisted of between 54 and 60 funds. ${ }^{8}$

In 1995 the average pension fund had Danish kroner (DKR) 12.5 billion, or Euro (EUR) 1.7 billion, in assets, increasing by 2004 to DKR 22.8, or EUR 3.1 billion. ${ }^{9}$ Funds with investments in the particular type of equity, had on average DKR 1.8 billion (EUR 240 million) invested in firms quoted on the Copenhagen Stock Exchange and DKR 210.8 (EUR 28.3) million in privately held firms in 1995. By 2004 this had risen to DKR 1.7 billion (EUR 231.9 million) and DKR 240.4 (EUR 32.3) million, respectively. In 2004, the total investment assets of pension funds in Denmark equaled DKR 1,230 (EUR 165) billion-equivalent to 92 percent of GDP. The total market value of investments in public and private firms was DKR 82.9 (EUR 11.1) billion and DKR 10.3 (EUR 1.4) billion, respectively. Although the portfolio weight on (domestic) equity appears to decline over the sample period, there has been an increasing allocation to foreign equity (unreported) which has kept the portfolio weight on equity relatively constant over the sample period.

Table 1 further shows the number of pension funds with investments in private firms from 1995 to 2004. The number of pension funds with investments in private firms has remained fairly constant around 40, with a slight decrease until 1999 followed by a larger increase until 2004. The pension funds' private equity investments' average share of total domestic equity investments decreased from 15.9 percent in 1995 to 8.7 percent in 2000 , but then increased to 26.5 percent in 2004 . Table 1 also reports the average number of investments in private firms reported in pension funds' annual reports. Throughout this paper we will refer to these as portfolio investments. The average number of reported portfolio investments per pension fund with such investments is between 9 and 13. However, as the reported investments include both direct investments and indirect

\footnotetext{
${ }^{8}$ The number of pension funds increased in 1998 and 1999 as a result of the entry of foreignowned pension funds and the creation of two temporary public pension funds. It decreases subsequently due to mergers of funds.

${ }^{9}$ The exchange rate between Danish Kroner and Euro is fixed at 7.45 Kroner per Euro.
} 
Table 1

Pension funds' investment assets from 1995 to 2004

This table provides descriptive statistics on the size of pension funds' investment assets. The sample consists of all pension funds in Denmark from 1995 to 2004. We report the number of pension funds, the mean and median market value of all investment assets, as well as domestic investments in public and private firms. In addition, we report the average and median share of total equity investments allocated to private equity and the number of reported portfolio investments (See Section 4.1 for details). All figures are in million 2000 Danish Kroner (DKR). The exchange rate of DKR to EUR is 7.45.

\begin{tabular}{|c|c|c|c|c|c|c|c|c|}
\hline \multirow[t]{3}{*}{ Year } & \multicolumn{8}{|c|}{ Pension fund investment assets } \\
\hline & \multicolumn{2}{|r|}{ All } & \multicolumn{2}{|c|}{ Public firms } & \multicolumn{4}{|c|}{ Private firms } \\
\hline & $\mathrm{N}$ & $\begin{array}{l}\text { Market } \\
\text { value }\end{array}$ & $\mathrm{N}$ & $\begin{array}{l}\text { Market } \\
\text { value }\end{array}$ & $\mathrm{N}$ & $\begin{array}{l}\text { Market } \\
\text { value }\end{array}$ & $\begin{array}{l}\% \text { total equity } \\
\text { allocation }\end{array}$ & $\begin{array}{l}\text { Number of reported } \\
\text { portfolio investments }\end{array}$ \\
\hline \multicolumn{9}{|c|}{ Mean (median) } \\
\hline 1995 & 55 & $\begin{array}{l}12487.8 \\
(3083.6)\end{array}$ & 49 & $\begin{array}{l}1787.6 \\
(481.2)\end{array}$ & 39 & $\begin{array}{l}210.8 \\
(88.6)\end{array}$ & $\begin{array}{c}15.9 \\
(13.7)\end{array}$ & $\begin{array}{c}13.4 \\
(11.0)\end{array}$ \\
\hline 1996 & 55 & $\begin{array}{l}13788.1 \\
(3283.6)\end{array}$ & 51 & $\begin{array}{l}1898.8 \\
(509.3)\end{array}$ & 38 & $\begin{array}{l}204.9 \\
(94.0)\end{array}$ & $\begin{array}{c}14.4 \\
(12.1)\end{array}$ & $\begin{array}{c}12.7 \\
(12.0)\end{array}$ \\
\hline 1997 & 55 & $\begin{array}{l}15422.0 \\
(3747.9)\end{array}$ & 52 & $\begin{array}{l}2419.5 \\
(612.1)\end{array}$ & 38 & $\begin{array}{l}187.2 \\
(80.3)\end{array}$ & $\begin{array}{l}13.6 \\
(9.5)\end{array}$ & $\begin{array}{l}12.0 \\
(8.0)\end{array}$ \\
\hline 1998 & 57 & $\begin{array}{l}16805.8 \\
(4473.8)\end{array}$ & 56 & $\begin{array}{l}2983.6 \\
(737.4)\end{array}$ & 36 & $\begin{array}{l}223.0 \\
(100.3)\end{array}$ & $\begin{array}{l}12.6 \\
(7.2)\end{array}$ & $\begin{array}{c}11.7 \\
(10.0)\end{array}$ \\
\hline 1999 & 60 & $\begin{array}{l}16929.0 \\
(4354.1)\end{array}$ & 53 & $\begin{array}{l}3064.5 \\
(865.1)\end{array}$ & 36 & $\begin{array}{c}212.6 \\
(108.0)\end{array}$ & $\begin{array}{l}10.9 \\
(6.9)\end{array}$ & $\begin{array}{l}11.0 \\
(8.0)\end{array}$ \\
\hline 2000 & 60 & $\begin{array}{l}18923.1 \\
(5568.9)\end{array}$ & 53 & $\begin{array}{l}3433.8 \\
(959.8)\end{array}$ & 38 & $\begin{array}{l}242.8 \\
(72.2)\end{array}$ & $\begin{array}{c}8.7 \\
(7.5)\end{array}$ & $\begin{array}{l}11.4 \\
(10.5)\end{array}$ \\
\hline 2001 & 60 & $\begin{array}{l}19848.7 \\
(6585.2)\end{array}$ & 54 & $\begin{array}{l}3215.2 \\
(995.7)\end{array}$ & 44 & $\begin{array}{l}253.7 \\
(58.7)\end{array}$ & $\begin{array}{l}15.4 \\
(8.2)\end{array}$ & $\begin{array}{l}11.1 \\
(9.0)\end{array}$ \\
\hline 2002 & 59 & $\begin{array}{l}19887.5 \\
(6484.7)\end{array}$ & 54 & $\begin{array}{l}2475.6 \\
(799.0)\end{array}$ & 45 & $\begin{array}{l}241.5 \\
(83.2)\end{array}$ & $\begin{array}{c}22.5 \\
(11.0)\end{array}$ & $\begin{array}{l}11.0 \\
(9.0)\end{array}$ \\
\hline 2003 & 58 & $\begin{array}{l}19538.0 \\
(6486.4)\end{array}$ & 51 & $\begin{array}{l}1554.3 \\
(426.3)\end{array}$ & 43 & $\begin{array}{l}250.8 \\
(73.8)\end{array}$ & $\begin{array}{c}28.1 \\
(16.4)\end{array}$ & $\begin{array}{c}9.4 \\
(8.0)\end{array}$ \\
\hline 2004 & 54 & $\begin{array}{l}22773.6 \\
(8131.5)\end{array}$ & 48 & $\begin{array}{l}1727.8 \\
(521.7)\end{array}$ & 43 & $\begin{array}{l}240.4 \\
(88.2)\end{array}$ & $\begin{array}{c}26.5 \\
(15.4)\end{array}$ & $\begin{array}{l}9.8 \\
(7.5)\end{array}$ \\
\hline
\end{tabular}

investments through funds, the total number of portfolio companies is higher. More important, the size and composition of the pension funds private investments have not changed significantly over the sample period. The average market value of the pension funds' investments in private firm grew by only 14 percent in real terms from 1995 to 2004. As this increase both captures adjustments of the market value of the current portfolio (old and window investments) and net new investments (replacing old with new investments), the increase due to net new investments is capped at 14 percent but is likely to be substantially lower. ${ }^{10}$ It follows from the discussion in Section 4.2 that adjustments

\footnotetext{
${ }^{10}$ Net new investments can only increase by 14 percent in the case where pension funds only adjust the market value of the private equity portfolio with the rate of inflation. If pension funds adjustments of market values (NAVs) are above the inflation rate, net new investments are substantially lower.
} 
to the market value of old and windows investments limit the conservativeness bias, as only net new investments can potentially bias the reported return. In addition, most of the increase occurred in 1998 and 2000, and by the end of 2004 the potential net new investments would have been held for 6.5 and 4.5 years, respectively. If pension funds are only conservative in the first years, the potential bias to the return on these potential net new investments is likely to be small. Moreover, the potential bias from conservative valuations is capped, by the weight of net new investments in the reported return. As net new investments over the period under conservative assumptions has a maximum portfolio weight of 12 percent $(0.14 / 1.14=0.12)$, these insights allow us to adjust the average reported return to private firms and ascertain that our results are unlikely to be explained by conservative valuations. Finally, we show that pension funds rarely report returns of zero percent - even in years where their portfolio of private firms did not change. This indicates that pension funds do adjust their assessment of NAVs of private firms.

Table 2 reports descriptive statistics on the composition of pension funds' private equity portfolios. We identify the private equity funds among the reported portfolio investments and utilize our rich firm-level data to identify each fund's portfolio. When we include fund investments in the pension funds' private equity portfolios, the total number of portfolio companies increases substantially. In 1995, the average pension fund portfolio consisted of 24 companies (12 direct and 12 indirect investments through 1 private equity fund), whereas the median pension fund portfolio included only 13 companies.

Perhaps more interestingly, Table 2 reveals that the bulk of investments by pension funds in Denmark are directly rather than indirectly held through funds. Direct investments are defined as direct ownership in private firms, whereas co-investments are included in indirect investments, as the pension fund often has invested in the same private equity fund. To measure the relative weight placed on direct versus indirect investments, we calculate the share of the book value of assets that are ultimately owned by pension funds. ${ }^{11}$ Direct investment's share of private equity portfolios is surprisingly high throughout the period, although the average share of book value of assets declined from 94 to 79 percent between 1995 and 2004. Direct investments are even more dominant in the median portfolio, where only a small fraction is allocated into indirect investments through funds. Although the reported returns include indirect investments through funds, these account for a trivial fraction of the overall returns. In a robustness check, when we exclude pension funds with more than 10 percent in private equity funds, we find little effect on our results. Thus, the evidence provided in this paper is mainly related to direct investments.

\section{The Risk-Return Tradeoff}

As private firms by nature are not publicly traded, the observed returns are partly based on a subjective assessment of market value. The fact that market values of private firms are unobservable induces a lack of synchronicity between "actual" and reported

\footnotetext{
${ }^{11}$ Market values on individual investments are not reported in the data. We therefore rely on book values to assess the total value of the portfolio. We calculate the share of book value of assets by multiplying the pension fund's share of ownership with each portfolio company's book value of assets. We thereby estimate the relative weights on direct versus indirect investments.
} 
Table 2

Pension funds' private equity portfolios from 1995 to 2004

This table provides descriptive statistics on the size of pension funds' private equity portfolios. The sample consists of the population of pension funds with investments in private firms within the period from 1995 to 2004. We distinguish between direct and indirect investment through private equity funds. We report the number of direct investments, whereas for indirect investments we report the number of funds and number of fund investments. The total number of portfolio companies is the number of direct investments plus the number of fund investments. We measure the relative size of each type by aggregating the share of book value of assets that ultimately are owned by pension funds.

\begin{tabular}{|c|c|c|c|c|c|c|}
\hline \multirow[t]{2}{*}{ Year } & \multicolumn{2}{|c|}{ Direct investments } & \multicolumn{3}{|c|}{$\begin{array}{l}\text { Indirect investments through private } \\
\text { equity funds }\end{array}$} & \multirow{2}{*}{$\begin{array}{c}\text { Total number } \\
\text { of portfolio } \\
\text { companies }\end{array}$} \\
\hline & $\begin{array}{l}\text { Number of } \\
\text { investments }\end{array}$ & $\begin{array}{l}\% \text { of total } \\
\text { assets }\end{array}$ & $\begin{array}{l}\text { Number } \\
\text { of funds }\end{array}$ & $\begin{array}{l}\text { Number of fund } \\
\text { investments }\end{array}$ & $\begin{array}{l}\% \text { of total } \\
\text { assets }\end{array}$ & \\
\hline \multicolumn{7}{|c|}{ Mean (median) } \\
\hline 1995 & $\begin{array}{c}12.2 \\
(10.5)\end{array}$ & $\begin{array}{c}94.3 \\
(100.0)\end{array}$ & $\begin{array}{c}1.1 \\
(0.0)\end{array}$ & $\begin{array}{l}11.8 \\
(0.0)\end{array}$ & $\begin{array}{c}5.7 \\
(0.0)\end{array}$ & $\begin{array}{c}24.0 \\
(13.0)\end{array}$ \\
\hline 1996 & $\begin{array}{c}11.6 \\
(11.0)\end{array}$ & $\begin{array}{c}93.4 \\
(100.0)\end{array}$ & $\begin{array}{l}1.1 \\
(0.0)\end{array}$ & $\begin{array}{l}14.4 \\
(0.0)\end{array}$ & $\begin{array}{l}6.6 \\
(0.0)\end{array}$ & $\begin{array}{c}26.0 \\
(14.0)\end{array}$ \\
\hline 1997 & $\begin{array}{l}10.8 \\
(8.0)\end{array}$ & $\begin{array}{c}91.4 \\
(100.0)\end{array}$ & $\begin{array}{l}1.1 \\
(0.0)\end{array}$ & $\begin{array}{l}17.6 \\
(0.0)\end{array}$ & $\begin{array}{l}8.6 \\
(0.0)\end{array}$ & $\begin{array}{c}28.4 \\
(16.0)\end{array}$ \\
\hline 1998 & $\begin{array}{l}10.2 \\
(7.0)\end{array}$ & $\begin{array}{c}89.1 \\
(99.7)\end{array}$ & $\begin{array}{l}1.5 \\
(1.0)\end{array}$ & $\begin{array}{l}18.3 \\
(0.0)\end{array}$ & $\begin{array}{l}10.9 \\
(0.0)\end{array}$ & $\begin{array}{l}28.5 \\
(16.0)\end{array}$ \\
\hline 1999 & $\begin{array}{c}9.1 \\
(7.0)\end{array}$ & $\begin{array}{c}85.9 \\
(98.9)\end{array}$ & $\begin{array}{l}1.9 \\
(2.0)\end{array}$ & $\begin{array}{l}21.8 \\
(3.0)\end{array}$ & $\begin{array}{l}14.1 \\
(0.0)\end{array}$ & $\begin{array}{c}30.9 \\
(16.0)\end{array}$ \\
\hline 2000 & $\begin{array}{c}9.1 \\
(7.5)\end{array}$ & $\begin{array}{c}84.3 \\
(99.0)\end{array}$ & $\begin{array}{c}2.3 \\
(2.0)\end{array}$ & $\begin{array}{c}22.5 \\
(5.0)\end{array}$ & $\begin{array}{l}15.7 \\
(0.0)\end{array}$ & $\begin{array}{c}31.6 \\
(12.5)\end{array}$ \\
\hline 2001 & $\begin{array}{c}8.9 \\
(7.0)\end{array}$ & $\begin{array}{c}82.2 \\
(99.2)\end{array}$ & $\begin{array}{c}2.3 \\
(1.0)\end{array}$ & $\begin{array}{c}24.4 \\
(9.0)\end{array}$ & $\begin{array}{l}17.8 \\
(0.8)\end{array}$ & $\begin{array}{c}33.3 \\
(15.0)\end{array}$ \\
\hline 2002 & $\begin{array}{c}8.5 \\
(6.5)\end{array}$ & $\begin{array}{c}80.8 \\
(98.1)\end{array}$ & $\begin{array}{c}2.5 \\
(1.5)\end{array}$ & $\begin{array}{c}28.8 \\
(12.0)\end{array}$ & $\begin{array}{l}19.2 \\
(1.9)\end{array}$ & $\begin{array}{c}37.3 \\
(18.0)\end{array}$ \\
\hline 2003 & $\begin{array}{c}7.1 \\
(5.0)\end{array}$ & $\begin{array}{c}81.8 \\
(98.7)\end{array}$ & $\begin{array}{c}2.3 \\
(1.0)\end{array}$ & $\begin{array}{c}23.1 \\
(4.0)\end{array}$ & $\begin{array}{l}18.2 \\
(1.3)\end{array}$ & $\begin{array}{c}30.2 \\
(14.0)\end{array}$ \\
\hline 2004 & $\begin{array}{c}8.0 \\
(6.5)\end{array}$ & $\begin{array}{c}79.2 \\
(97.9)\end{array}$ & $\begin{array}{c}1.8 \\
(1.0)\end{array}$ & $\begin{array}{c}20.0 \\
(5.0)\end{array}$ & $\begin{array}{c}20.8 \\
(2.1)\end{array}$ & $\begin{array}{c}28.0 \\
(12.5)\end{array}$ \\
\hline
\end{tabular}

returns. Moreover, as Gompers and Lerner (2001) point out, the use of conservative valuation practices provides a negative bias to the covariance with the market portfolio, which in turn makes investments in private firms appear more attractive from a portfolio perspective. Thus, the stale pricing problem makes it difficult to apply the standard techniques to risk-adjust the observed returns.

Because of these obstacles, the majority of papers in prior literature assume a market model with beta equal to one to assess abnormal performance (Moskowitz and Vissing-Jørgensen (2002); Kaplan and Schoar (2005); Lerner, Schoar, and Wongsunwai (2007), among others). Few papers attempt to risk-adjust the return on private equity: ${ }^{12}$

\footnotetext{
${ }^{12}$ Other studies have attempted to assess the risk by estimating the correlation between private and public equity returns using data that are less affected by the lack of synchronicity:
} 
Woodward (2004) and Jones and Rhodes-Kropf (2004) estimate fund alpha and betas by regressing returns on both contemporaneous and lagged risk factors. ${ }^{13}$ In a recent paper, Dreissen, Lin, and Phalippou (2009) show that such an approach might generate large biases in both risk exposure and abnormal performance. To avoid this problem, Dreissen et al. (2007) estimate a factor pricing model by applying GMM to a set of price restrictions and find significantly negative alphas for both venture capital and buyout funds. Alternatively, Phalippou and Gottschalg (2009) use an industry matching approach to estimate the portfolio beta and risk adjust returns.

Our time series of returns to private firms share the statistical problems mentioned above. However, the novelty of our data allows us to assess the risk of every portfolio company and to subsequently characterize the risk at the portfolio level.

\subsection{The risk of investments in private firms}

To open the discussion of risk, we provide descriptive statistics on the total risk of private equity as an asset class. We then document the risk-level of individual pension funds' private equity portfolios, a more relevant measure for pension fund decision-making.

Table 3 reports descriptive statistics on the return to investments in public and private firms. The descriptive statistics include the total number of pension funds, the average return, the standard deviation, the 10th, 50th and 90th percentiles of the return across pension funds for both public and private firms. Interestingly, the variation in private equity returns is substantially larger than for public equity in all years. In fact, in all years, the standard deviation on yearly private equity returns is at least twice as high as for public equity returns. Moreover, when we (in unreported regressions) estimate the alpha and beta measures of risk using the yearly observations in Table 3 , we find a beta of 0.47, whereas alpha is negative and insignificant. Economically, the private equity alpha is quite large ( -2.2 percent), even though the short sample period makes it difficult to estimate coefficients with precision.

We proceed by analyzing the risk characteristics of individual pension funds' private equity portfolios, which is more directly related to pension fund decision-making. We do this in two steps: First we estimate the pension funds' private equity portfolio beta using an industry matching approach similar to Phalippou and Gottschalg (2009). Second, following Daniel, Grinblatt, Titman, and Wermers (1997) we characterize the risk by estimating the average corresponding size and book-to-market quintiles of the private equity portfolios. To cover all pension funds' investments in private firms (i.e., industries) we use stocks from six Northern European markets (Denmark, Germany, the Netherlands, Norway, Sweden, and the U.K.). We obtain identical results when risk characteristics (in an unreported robustness check) are estimated using U.S. stocks quoted on the New York Stock Exchange. Results are reported in Table 4.

Moskowitz and Vissing-Jørgensen (2002) find a correlation of 0.7 between the book equity return of public and private equity from 1963 to 1999. Similarly, Phalippou and Zollo (2005b) find that the performance of private equity funds co-varies positively with both business cycles and stock market returns.

${ }^{13}$ As the stale pricing problem is equivalent to the problem of measuring risk for thinly traded stocks, Woodward (2004) and Jones and Rhodes-Kropf (2004) apply the Scholes and Williams (1977) technique of including contemporaneous and lagged market returns. 
Table 3

Average yearly return on pension funds' equity investments from 1995 to 2004

This table summarises the average yearly return (in percent) of pension fund equity investments from 1995 to 2004. We report the following for both investments in public and private firms, respectively: number of pension funds, average return, cross-fund standard deviation, the 10th (P10), 50th (Median), and 90th (P90) percentiles of the distribution of pension fund returns.

\begin{tabular}{|c|c|c|c|c|c|c|c|c|c|c|}
\hline \multirow[t]{2}{*}{ Year } & \multicolumn{5}{|c|}{ Return to public firms (\%) } & \multicolumn{5}{|c|}{ Return to private firms $(\%)$} \\
\hline & $\mathrm{N}$ & $\begin{array}{c}\text { Mean } \\
\text { (Std. dev.) }\end{array}$ & P10 & Median & P90 & $\mathrm{N}$ & $\begin{array}{c}\text { Mean } \\
\text { (Std. dev.) }\end{array}$ & $\mathrm{P} 10$ & Median & P90 \\
\hline 1995 & 49 & $\begin{array}{c}7.44 \\
(3.30)\end{array}$ & 3.3 & 8.1 & 10.1 & 39 & $\begin{array}{l}-0.41 \\
(10.36)\end{array}$ & -11.5 & -1.0 & 10.2 \\
\hline 1996 & 51 & $\begin{array}{l}31.19 \\
(7.13)\end{array}$ & 26.4 & 30.7 & 37.2 & 38 & $\begin{array}{c}1.02 \\
(12.05)\end{array}$ & -14.1 & 1.1 & 12.9 \\
\hline 1997 & 52 & $\begin{array}{c}33.88 \\
(11.07)\end{array}$ & 20.0 & 37.5 & 45.1 & 38 & $\begin{array}{c}16.24 \\
(22.436)\end{array}$ & 0.0 & 13.1 & 35.2 \\
\hline 1998 & 56 & $\begin{array}{c}-3.69 \\
(6.17)\end{array}$ & -9.0 & -4.1 & -1.5 & 36 & $\begin{array}{c}12.15 \\
(31.34)\end{array}$ & -8.1 & 4.8 & 37.2 \\
\hline 1999 & 53 & $\begin{array}{l}22.71 \\
(7.13)\end{array}$ & 15.3 & 22.8 & 28.7 & 36 & $\begin{array}{c}1.78 \\
(14.98)\end{array}$ & -9.7 & 0.6 & 14.2 \\
\hline 2000 & 53 & $\begin{array}{c}20.20 \\
(10.05)\end{array}$ & 4.3 & 21.5 & 31.7 & 38 & $\begin{array}{c}27.27 \\
(40.66)\end{array}$ & -6.9 & 20.9 & 86.3 \\
\hline 2001 & 54 & $\begin{array}{r}-13.94 \\
(5.78)\end{array}$ & -20.3 & -13.7 & -10.7 & 44 & $\begin{array}{l}-5.54 \\
(24.85)\end{array}$ & -24.9 & -3.6 & 6.9 \\
\hline 2002 & 54 & $\begin{array}{r}-20.51 \\
(6.37)\end{array}$ & -27.2 & -20.7 & -14.0 & 45 & $\begin{array}{l}-6.09 \\
(14.99)\end{array}$ & -21.2 & -6.8 & 13.3 \\
\hline 2003 & 51 & $\begin{array}{c}30.40 \\
(11.16)\end{array}$ & 22.0 & 30 & 36.8 & 43 & $\begin{array}{l}-0.59 \\
(19.93)\end{array}$ & -20.0 & 2.1 & 12.0 \\
\hline 2004 & 48 & $\begin{array}{c}25.30 \\
(5.63)\end{array}$ & 20.5 & 25.4 & 31.8 & 43 & $\begin{array}{c}5.15 \\
(9.15)\end{array}$ & -1.6 & 4.1 & 16.5 \\
\hline
\end{tabular}

To assess the portfolio beta, we estimate the beta of individual stocks using return data from the preceding 60 months. The industry beta is then calculated as a value-weighted average of individual betas for firms within the industry. We match the pension funds' portfolio investments to the industry by using both the two-digit industry level and a best match approach. The best match approach favors the four-digit industry beta; we move to the two-digit industry beta if there are no publicly traded firms within the four- or three-digit groupings. We then average across pension funds using both equal and value weights in each year. Table 4 shows that the average private equity portfolio beta from 1995 to 2004 is 1.012 using the average two-digit industry betas from Northern European stocks as benchmark. When we value weight, the average betas drop to 0.86 . We obtain betas of similar magnitude when we use the best match approach, which favors the four-digit industry beta, and move to the two-digit level if there are no publicly traded firms within the four- and three-digit groupings. Thus, pension funds' private equity portfolios appear to have average market risk with a beta around 1 .

The second step in our risk assessment is to estimate the private equity portfolios' exposure to common risk factors. To do this we apply the approach developed by Daniels et al. (1997), which characterizes the risk of an investment by the corresponding quintile 
Table 4

Risk characteristics of investments in private firms

This table shows the risk characteristics of pension funds' private equity portfolios. We report the estimated portfolio beta on pension funds' investments in private firms, and the average risk factor quintile for size and market-to-book portfolios. To estimate the average beta we assume that the beta on each portfolio investment can be represented by the value weighted average of the beta on individual stocks within the industry. We estimate the beta on individual stocks using monthly returns from the preceding 60 months. We match the investments to the industry using both the 2-digit industry code and a best match approach. The best match approach matches the investment to the industry beta on the lowest possible industry level (see Section 5.1 for details). To estimate the average risk factor quintile for size and market-to-book factors we follow Daniel et al. (1997). To calculate the average characteristic, the quintile benchmark portfolio number (1 through 5) is identified, each year, for each investment in private firms held by a pension fund for both characteristics. Size portfolio 1 consists of small stocks, whereas book-to-market portfolio 1 consists of low book-to-market stocks. The market value of equity of each private equity portfolio company is calculated as the difference between market value of assets and book value of debt. Market value of assets is estimated by multiplying the median market-to-book ratio within the 2-digit industry with the book value of assets. Book to market ratio is book value of equity over the estimated market value of equity. Finally, pension fund average benchmark portfolio numbers are averaged across all funds each year. We use Northern European stocks from Denmark, Germany, the Netherlands, Norway, Sweden and the UK to estimate industry betas and risk factors. Panel A uses equal weights on each investment, whereas Panel B uses value weights.

\begin{tabular}{|c|c|c|c|c|c|}
\hline \multirow[t]{3}{*}{ Benchmark: } & \multirow{3}{*}{$\begin{array}{l}\text { Number of } \\
\text { portfolio } \\
\text { companies }\end{array}$} & \multirow{2}{*}{\multicolumn{2}{|c|}{$\begin{array}{c}\begin{array}{c}\text { Average portfolio } \\
\text { beta }\end{array} \\
\text { Industry level }\end{array}$}} & \multirow{2}{*}{\multicolumn{2}{|c|}{$\begin{array}{c}\begin{array}{c}\text { Average risk factor } \\
\text { quintile }\end{array} \\
\text { Factor }\end{array}$}} \\
\hline & & & & & \\
\hline & & 2-digit & Best match & Size & Market to book \\
\hline \multicolumn{6}{|c|}{ Panel A: Equal weighted } \\
\hline 1995 & 271 & 0.963 & 0.921 & 1.6 & 3.3 \\
\hline 1996 & 300 & 0.980 & 0.898 & 1.5 & 3.4 \\
\hline 1997 & 351 & 1.004 & 0.946 & 1.6 & 3.2 \\
\hline 1998 & 372 & 1.002 & 0.955 & 1.6 & 3.6 \\
\hline 1999 & 388 & 0.981 & 0.988 & 1.6 & 3.2 \\
\hline 2000 & 347 & 0.979 & 0.988 & 1.6 & 3.1 \\
\hline 2001 & 393 & 1.017 & 0.974 & 1.6 & 3.2 \\
\hline 2002 & 414 & 1.041 & 1.014 & 1.8 & 3.2 \\
\hline 2003 & 417 & 1.048 & 1.038 & 2.1 & 2.9 \\
\hline 2004 & 534 & 1.058 & 1.048 & 1.8 & 3.2 \\
\hline Average 1995-2004 & 3787 & 1.012 & 1.004 & 1.6 & 3.2 \\
\hline \multicolumn{6}{|c|}{ Panel B: Value weighted } \\
\hline 1995 & 271 & 0.900 & 0.907 & 1.7 & 3.2 \\
\hline 1996 & 300 & 0.856 & 0.860 & 1.7 & 3.4 \\
\hline 1997 & 351 & 0.848 & 0.849 & 1.8 & 3.0 \\
\hline 1998 & 372 & 0.836 & 0.846 & 1.8 & 3.5 \\
\hline 1999 & 388 & 0.845 & 0.855 & 1.7 & 3.3 \\
\hline 2000 & 347 & 0.859 & 0.849 & 1.7 & 3.2 \\
\hline 2001 & 393 & 0.854 & 0.854 & 1.7 & 3.3 \\
\hline 2002 & 414 & 0.838 & 0.866 & 1.9 & 3.2 \\
\hline 2003 & 417 & 0.854 & 0.891 & 2.1 & 2.8 \\
\hline 2004 & 534 & 0.907 & 0.918 & 1.8 & 3.1 \\
\hline Average 1995-2004 & 3787 & 0.860 & 0.869 & 1.8 & 3.2 \\
\hline
\end{tabular}


number in a Fama-French model. We focus on size and book-to-market factors. In order to characterize the risk of the individual pension fund portfolios, we identified the two corresponding characteristic quintile numbers for each private investment held by a given pension fund in a given year. To do this, we estimate the market value of equity for each portfolio company by scaling book value of assets with the median marketto-book ratio on assets at the two-digit industry level and subtract book value of debt. The book-to-market ratio is calculated as the book value of equity over the estimated market value of equity. Given the estimates of market value and book-to-market ratio, the corresponding characteristic quintile numbers were found using Northern European stocks as benchmark. ${ }^{14}$ We then computed the portfolio-weighted quintile number for each pension fund for each of the two characteristics. The portfolio characteristics were then averaged across all funds during a year using both equal and value weights.

Table 4 reports the average risk characteristic per year using equal and value weights. For all pension funds over the period of 1995 to 2004, the average size quintile number is 1.6. Size quintile 1 (5) consists of small (large) stocks, whereas book-to-market quintile 1 (5) consists of low (high) book-to-market stocks. Thus, pension funds have a high portfolio weight on private firms that are small relative to public firms. In addition, the average book-to-market quintile number is 3.2. Thus, pension funds have a slight tendency to overweight stocks with a high book-to-market value of equity. A similar conclusion emerges when we use value weighted average of the individual pension funds' portfolio characteristics. Given the well-documented factor risk-premia (Fama and French, 1993) the expected return on a portfolio with high load on the size factor (small minus big) and a modest load on the book-to-market factor (high minus low) is higher than the return to the market portfolio. Moreover, such a portfolio would have higher risk than the market portfolio.

To summarize, the evidence suggests that pension fund investments in private firms are at least as risky as the market portfolio.

\subsection{The return to investments in private firms}

We start the discussion of the return to investments in private firms by comparing the return to the market return on public firms. Moreover, as the pension funds also invest in public equity, we benchmark the return to private firms to the same pension fund's public equity return. We thereby control for pension fund-invariant heterogeneity (e.g., risk attitude) as this will affect both the realized public and private equity returns. We then provide a risk-adjusted estimate of the return to private firms. As the main purpose is to document the underperformance of the investments in private firms, we deliberately use the most conservative risk assessment from our prior analysis to estimate the abnormal return. The attractiveness of this conservative benchmark is that our estimate then provides a lower bound on the actual abnormal return, since any alternative risk adjustment will enhance the negative abnormal return and strengthen the premise of the paper. Table 5 summarizes the estimated abnormal return to investment in private firms for pension funds with such investments in all years from 1995 to 2004 .

\footnotetext{
${ }^{14}$ Essentially we sort the Northern European stocks in each year and form Fama-French quintile portfolios. We then find the corresponding quintile number for each risk factor for each private equity investment. See Daniel et al. (1997) for a thorough explanation of the risk characteristics approach.
} 
Table 5

Return to investments in private firms

This table reports the average annual abnormal return to private equity investments by pension funds in Denmark from 1995 to 2004. Panel A uses the market index on the Copenhagen Stock Exchange as benchmark for the private firms by assuming that investments in private firms have a beta equal to one. Panel B uses the pension funds' realised return to domestic public equity as benchmark, whereas Panel C reports use a risk-adjusted benchmark. Thus, Panel $\mathrm{C}$ reports the average market return with risk equivalent to the portfolio beta on the private equity investments. We only include pension funds with private equity investments for all years within the period. We use a standard mean comparison test to evaluate whether public and private equity provided identical returns. We report the difference and the $p$-value that emerge from the test of comparable means.

Average annual return $(\%)$

\begin{tabular}{|c|c|c|c|c|}
\hline \multicolumn{2}{|c|}{ Private firms } & \multicolumn{2}{|c|}{ Benchmark } & $\begin{array}{l}\text { Abnormal return to } \\
\text { private firms }\end{array}$ \\
\hline $\mathrm{N}$ & $\begin{array}{c}\text { Mean } \\
\text { (std.dev.) }\end{array}$ & $\mathrm{N}$ & $\begin{array}{c}\text { Mean } \\
\text { (std.dev.) }\end{array}$ & $P$-value \\
\hline
\end{tabular}

Panel A: Market return

Equal weighted $\quad 340$

340

340

13.148

$-7.625^{* * *}$

$[0.000]$

Value weighted

340

8.328

340

(19.55)

13.148

(19.55)

(21.32)

$-4.820^{* * *}$

[0.000]

Panel B: Pension funds' public equity return

\begin{tabular}{|c|c|c|c|c|c|c|}
\hline Equal weighted & 340 & $\begin{array}{r}5.523 \\
(22.74)\end{array}$ & 340 & $\begin{array}{r}13.350 \\
(20.20)\end{array}$ & $-7.827^{* * *}$ & {$[0.000]$} \\
\hline Value weighted & 340 & $\begin{array}{r}8.328 \\
(21.32)\end{array}$ & 340 & $\begin{array}{r}13.645 \\
(20.39)\end{array}$ & $-5.316^{* * *}$ & {$[0.001]$} \\
\hline \multicolumn{7}{|c|}{ Panel C: Risk-adjusted market return } \\
\hline Equal weighted & 340 & $\begin{array}{r}5.523 \\
(22.74)\end{array}$ & 340 & $\begin{array}{c}12.143 \\
(16.45)\end{array}$ & $-6.620^{* * *}$ & {$[0.000]$} \\
\hline Value weighted & 340 & $\begin{array}{r}8.328 \\
(21.32)\end{array}$ & 340 & $\begin{array}{c}12.250 \\
(16.70)\end{array}$ & $-3.922^{* * *}$ & {$[0.001]$} \\
\hline
\end{tabular}

Table 5 shows that the average annual return to private firms is 5.52 percent when we use equal weights on each pension fund. As evident from Table 1 the pension funds and their investments in private firms vary in terms of size. Thus, when we value weight, using the average reported market value of private firms within the year, the estimated average annual return to private firms increases to 8.33 percent.

More interestingly, Table 5 reports the abnormal return to private firms using three benchmarks: market return (Panel A); pension funds' return to investments in public firms (Panel B); and risk-adjusted market return (Panel C).

Panel A uses the marked return on Copenhagen Stock Exchange as benchmark for the return to private firms. As the market index returned 13.15 percent per year on average, the estimated annual abnormal return to private equity equals -7.63 and -4.82 percent using equal and value weights, respectively. Using a standard F-test to test whether the returns on the market index and private firms are identical, we reject the null hypothesis 
at the 1 percent level. ${ }^{15}$ Thus, the return to private firms has been significantly lower than the average return to public equity.

Panel B reports the estimated abnormal return when we use the pension funds' realized return to their (domestic) investments in public firms as benchmark. As pension funds realized on average a slightly higher return to public firms compared to the market index, the abnormal return to private firms decreases. Again, we strongly reject the null hypothesis of comparable means. Thus, Panel B shows that pension funds realized a significantly lower return from their investments in private firms. This raises the bar for potential explanations to the private equity premium puzzle, as the acceptance of the poor risk-return tradeoff cannot be explained by pension fund-invariant heterogeneity.

Finally, Panel C provides a risk-adjusted estimate of the performance of private firms. To provide a conservative estimate of the abnormal return to private firms, we risk-adjust using the most conservative assessment of risk from the analysis in the prior section, which is the estimated private equity portfolio betas from Table 4 . Thus, the risk of the public equity benchmark in Panel $\mathrm{C}$ is assumed to be equivalent to the estimated risk of the private equity portfolio for each individual pension fund. Among the four estimations of beta in Table 4, we use the one with the lowest average risk assessment of the private equity portfolios, which is the value-weighted portfolio beta using industry matching on the 2-digit industry level. Consistently, the average equal-weighted (valueweighted) expected return decreases to 12.14 (12.25) percent per year. However, the risk-adjusted gap in returns between private and public equity is still economically and statistically significant: Using equal weights, pension funds' private equity returns lag as much as 6.62 percentage points per year, whereas with value weights the gap in returns equals 3.92 percentage points per year. These differences are statistically significant at the 1-percent level. Moreover, any alternative risk-adjustment using either betas or the risk factors from Table 4 would enhance the negative abnormal return to private equity. Thus, our most conservative estimate shows that pension funds have received a negative abnormal return of 392 basis points per year over 10 years.

\subsection{Potential bias from conservative valuations}

To ascertain that these results are not driven by conservative valuation one can adjust the reported returns for this potential bias by taking the extreme position that pension funds only adjust the market value of their investments with the rate of inflation. In such cases, the reported returns are biased toward zero by the increase in net new investments of 14 percent over the sample period. If pension funds are extremely conservative the return on net new investments is equal to zero. Thus, at maximum the potential bias from conservative valuations is equivalent to the reported return being confounded by a 12 percent portfolio weight on a zero percent return. ${ }^{16}$ Adjusting the reported return for

\footnotetext{
${ }^{15}$ We perform a simple F-test of comparable means. As a robustness check, the Wilcoxon rank sum test as well as a test on the equality of medians have been performed. Both non-parametric tests reject the null at the 1 percent level.

${ }^{16}$ Because pension funds under this assumption never adjust the market value of old and window investments, the increase of 14 percent in reported market values in Table 1 is entirely a consequence of net new investments (replacing old with new investments). The portfolio weight on the net new investments investments is equal to 12 percent as $0.14 / 1.14=$ 0.12 . Returns can be adjusted for the potential bias by using the insight that the reported
} 
the effect of the bias yields an upper bound on the unbiased return to investment in private firms of 6.91 percent and 9.30 percent using equal and value weights, respectively. Thus, it follows that the maximum bias resulting from conservative valuations has a relatively small effect on our results as the underperformance equals around 3 percent per year.

If pension funds are conservative in their assessment of NAVs, the conservativeness would imply that pension funds frequently report returns of zero percent. In the sample there is 13 observations of zero percent return out of 340 pension fund-year observations which is equivalent to a frequency of $3.8 \%$. If we focus on pension funds with no change in their reported portfolio investments (no exit or new investments), only 7 out of 80 fundyears are zero returns. Thus, more than 90 percent of pension funds actively adjust their NAVs when there is no change to their underlying portfolio. More interestingly, these fund report average adjustments equivalent to a 9.8 percent annual return. Collectively, these observations suggest that pension funds are not extremely conservative when they assess NAVs of private firms.

As an additional test, in (unreported) regressions of the abnormal return on the increase to the reported market value of private equity we find a positive but insignificant correlation between increasing market value and the abnormal return. Thus, pension funds with the largest increases in the reported market value also reported the highest return to private firms, which is the opposite of what we should find if the results are driven by conservative valuation bias. Moreover, controlling for changes in the portfolio allocation the intercept equals -8.46 percent and is statistically significant at the 1 percent level. Thus, the return gap persists after controlling for potential bias due to the potential increase in net investments.

Another important caveat to the estimated abnormal return on private equity is that the data covers a window of 10 years. Short time series is a problem shared with most of the literature on private equity returns. In our case, the length of the window is determined by the implementation of the mandatory reporting of returns by the government in 1995 . Prior to 1995, pension funds reported the return on private and public equity collectively. However, two pension funds have voluntarily reported the return on private equity for a substantially longer time period. Although voluntarily reported returns might be biased toward successful investments, this potential bias will make it harder to establish the performance gap.

Interestingly, these two pension funds are among the largest investors in private equity. The first pension fund, Lønmodtagernes Dyrtidsfond (LD), is by far the largest and most experienced private equity investor, with more than 300 investments to date. ${ }^{17} \mathrm{LD}$ reports returns from 1980 to 2004, and over this period, the return on private equity lagged as much as 8.8 percentage points per year. Similarly, Pensionskassen for Magistre og Psykologer (MP Pension), reports an underperformance of 3.6 percentage points per year over the fifteen-year period from 1990 to 2004. Although we cannot provide systematic evidence of the documented underperformance using a longer time series, the two examples highlight the puzzling finding that even professional investors such as pension funds seem to get a poor risk-return tradeoff from investing in private equity.

return must equal $0.88 *$ actual return $+0.12 * 0 \%$. Thus, the upper-bound on the unbiased return to investment in private firms equals to $6.91 \%$ (9.30\%) using equal (value) weights.

${ }^{17}$ In the sample period, LD accounts for between 13 and 19 percent of the market value of all investments in private firms. Moreover, despite Denmark's relative small size, LD is among the 300-largest pension funds in the World (Watson Wyatt, 2006). 
In addition, the sheer size of the documented underperformance reduces the likelihood that the results are driven by the length of the sample period.

In summary, we provide strong evidence that the return to investments in private firms has been significantly lower than the return to public equity within the ten-year period of 1995 to 2004. The difference is large both economically and statistically. Our most conservative risk-adjusted estimate shows that private equity investments have provided a 392-basis-point negative abnormal return per annum.

\section{New Evidence on the Private Equity Premium Puzzle}

This section exploits our novel data on pension funds' private equity holdings to test the potential explanations for why pension funds invest in private equity despite the poor risk-return tradeoff. Moreover, as the pension funds realized a poor return relative to their own public equity investments, any potential explanation for why pension funds invest in private equity should explain this relative difference as well.

In their seminal paper, Moskowitz and Vissing-Jørgensen (2002) list a number of potential explanations for why entrepreneurs willingly invest a substantial fraction of their wealth in a single private firm: Entrepreneurs might have a high risk tolerance (i.e., low risk aversion), which will reduce the disutility from poor diversification. Likewise, entrepreneurs might have a preference for skewed returns and, therefore, accept a lower mean return in exchange for the large potential upside; in this respect, entrepreneurs can be characterized as participating in a tournament. Entrepreneurial activity could also be encouraged by the ability to derive pecuniary and non-pecuniary benefits. Pecuniary benefits take the form of consumption through the firm (e.g., perks), whereas nonpecuniary benefits are prestige, reputation, and the value of being your own boss, among others. Finally, Moskowitz and Vissing-Jørgensen point to over-optimism and misperceived risk as explanations for entrepreneurial investments in private equity. While the motivation for entrepreneurial investments might seem very different from armslength investments in private firms by pension funds, we note that pension funds manager might also commit investment mistakes or be motivated by agency problems inside the pension fund. In addition to this list, we consider a number of other explanations related to pension funds, including relationship-building and politically motivated investments.

\subsection{Risk tolerance and preference for skewness}

Prior research on institutional investors and their investment preferences has shown that institutions, and in particular pension funds, tend to be prudent (see Del Guercio (1996), and Gompers and Metrick (2001), among others). Prudent investors invest in less risky stocks, which is inconsistent with having a high risk tolerance and/or a preference for skewed returns. Thus, unlike entrepreneurs and individuals, pension funds are unlikely to have a high risk tolerance or a preference for skewed returns.

\subsection{Pecuniary and non-pecuniary benefits to pension fund managers}

Pecuniary and non-pecuniary benefits have been suggested by both Hamilton (2000) and Moskowitz and Vissing-Jørgensen (2002) as explanations for why people become entrepreneurs. Pecuniary benefits usually take the form of consumption through the firm. In essence, these benefits are measurement errors when we evaluate the return 
Table 6

Private benefits to the management of pension funds through board appointments

This table shows the number of new board members in pension fund portfolio companies subsequent to the investment by a pension fund. We include direct investments, private equity funds and private equity fund portfolios in the sample of portfolio companies. We report the number of new board members and the number of managers and board members of the pension fund. We further partition on whether the new members joined the board while the pension fund was still an owner and after the fund sold out, respectively.

\begin{tabular}{|c|c|c|c|c|c|}
\hline & \multirow{3}{*}{$\begin{array}{c}\text { New board } \\
\text { members in } \\
\text { portfolio } \\
\text { companies }\end{array}$} & \multicolumn{4}{|c|}{$\begin{array}{l}\text { Number of managers and } \\
\text { board members of pension } \\
\text { funds among new board } \\
\text { members of portfolio } \\
\text { companies }\end{array}$} \\
\hline & & \multicolumn{2}{|c|}{$\begin{array}{l}\text { Pension } \\
\text { fund } \\
\text { managers }\end{array}$} & \multicolumn{2}{|c|}{$\begin{array}{l}\text { Pension } \\
\text { fund board } \\
\text { members }\end{array}$} \\
\hline & & $\mathrm{N}$ & $\%$ & $\mathrm{~N}$ & $\%$ \\
\hline $\begin{array}{l}\text { All new boards members after } \\
\text { investment by a pension fund }\end{array}$ & 2514 & 26 & 1.0 & 24 & 1.0 \\
\hline $\begin{array}{l}\text { - New board members while } \\
\text { pension fund is an owner }\end{array}$ & 1774 & 22 & 1.2 & 19 & 1.1 \\
\hline $\begin{array}{l}\text { - New board members after the } \\
\text { pension fund sold out }\end{array}$ & 740 & 4 & 0.5 & 5 & 0.7 \\
\hline
\end{tabular}

to private equity using survey data, since these benefits are unreported. Non-pecuniary benefits, on the other hand, include prestige, reputation, and the value of "being your own boss", which are difficult to quantify.

Although it seems reasonable to argue that pension funds are less likely than individuals to obtain pecuniary or non-pecuniary benefits from their investments in private firms, pension funds are run by managers who might be self-interested. To address this potential explanation, we examine whether pension fund managers get elected to the board; we posit that, as directorship positions are paid and prestigious, accumulation of board seats capture both pecuniary and non-pecuniary benefits accruing to fund managers.

Our rich data allow us to investigate the relationship between the managers of a pension fund and the appointment of new board members in portfolio companies subsequent to investment. Within the period of 1995 to 2004,39 pension funds reported having at least 1 investment in a private firm where either the cash flow or the voting stake exceeded 5 percent. In the course of this ten-year period, pension funds invested directly in 333 portfolio companies and indirectly in 749 companies through 33 private equity funds. To complete the analysis, we identify new board members in both portfolio companies and private equity funds. In total, the sample consists of 4,355 firm-year observations, and with this dataset, we identify all new board members subsequent to an investment by a pension fund. We then check whether the board members are managers or directors of the investing pension fund, using the social security number as identifier.

Table 6 shows that a total of 2,514 new board members were appointed in portfolio companies and private equity funds subsequent to an investment by a pension fund. Of 
these 2,514 new board members, only 26 ( 1 percent) were directors in the pension fund at the time that the investment decision was taken. Similarly, 24 (less than 1 percent) of the newly appointed board members were members of the board of the investing pension fund. Table 6 conditions on the timing of the appointment of new board members. Evidently, most appointments to portfolio company boards of managers of the investing pension funds took place while the pension fund was an owner. The lack of a significant accumulation of board seats by the management of pension funds is inconsistent with the idea that these investments are driven by self-interested managers. Thus, using a very direct measure of pecuniary and non-pecuniary benefits, we do not find significant evidence of this as the driving force behind the investments.

Arguably, there are many more indirect ways to obtain private benefit from portfolio companies than by joining the board. These are difficult to quantify and to measure. We argue that if private benefits are important to the management of pension funds, one of the most likely manifestations would be board representation. We base this belief on the positive motive for board representation - monitoring of the investment. Monitoring of portfolio companies might provide a perfect blind for managers to join a board and, at the same time, to receive private benefits. Still, we find little evidence backing this explanation for pension fund investment in private firms.

\subsection{Over-optimism and misperceived risk}

In this section, we scrutinize the source of the low return to investments in private firms. We make use of our detailed firm-level data to distinguish whether poor performance of the underlying portfolio of privately held firms, missing capital gains, or both are the driving forces behind the low returns. Our empirical strategy is, therefore, to test whether underlying performance has been lower in pension fund portfolio companies. We focus on portfolio companies and therefore exclude private equity funds We use a simple matching procedure for each portfolio company to form a matched sample of non-portfolio companies. We construct matched samples using both two-digit and three-digit industry codes. The matched sample consists of the 10 (5) firms within the two-digit (three-digit) industry code with the closest proximity measured by firm size (book value of assets) to each portfolio company in each year. This match is repeated for all portfolio companies to form a fairly homogeneous sample of control firms within the period of 1995 to 2004 .

Table 7 summarizes the results from regressions of return on assets (defined as EBIT over assets) on a portfolio company dummy. We run ten yearly cross-section regressions as well as a pooled regression. To provide an overview, Table 7 therefore reports the average coefficient; the average marginal effect; and the number of positive, negative, and significant coefficients for the cross-section models, whereas we report the coefficient and t-statistics for the pooled model. In all regressions we control for industry and size-specific effects by including a dummy for each portfolio company and the corresponding matched sample. ${ }^{18}$ In addition, our specification includes firm age and leverage as control variables to ensure that our results are not driven by observable characteristics unrelated to industry and size.

\footnotetext{
${ }^{18}$ To reduce the influence of outliers, we weight the observations with book value of assets. In addition, we have performed median regressions as a robustness check and obtained results of a similar order of magnitude.
} 


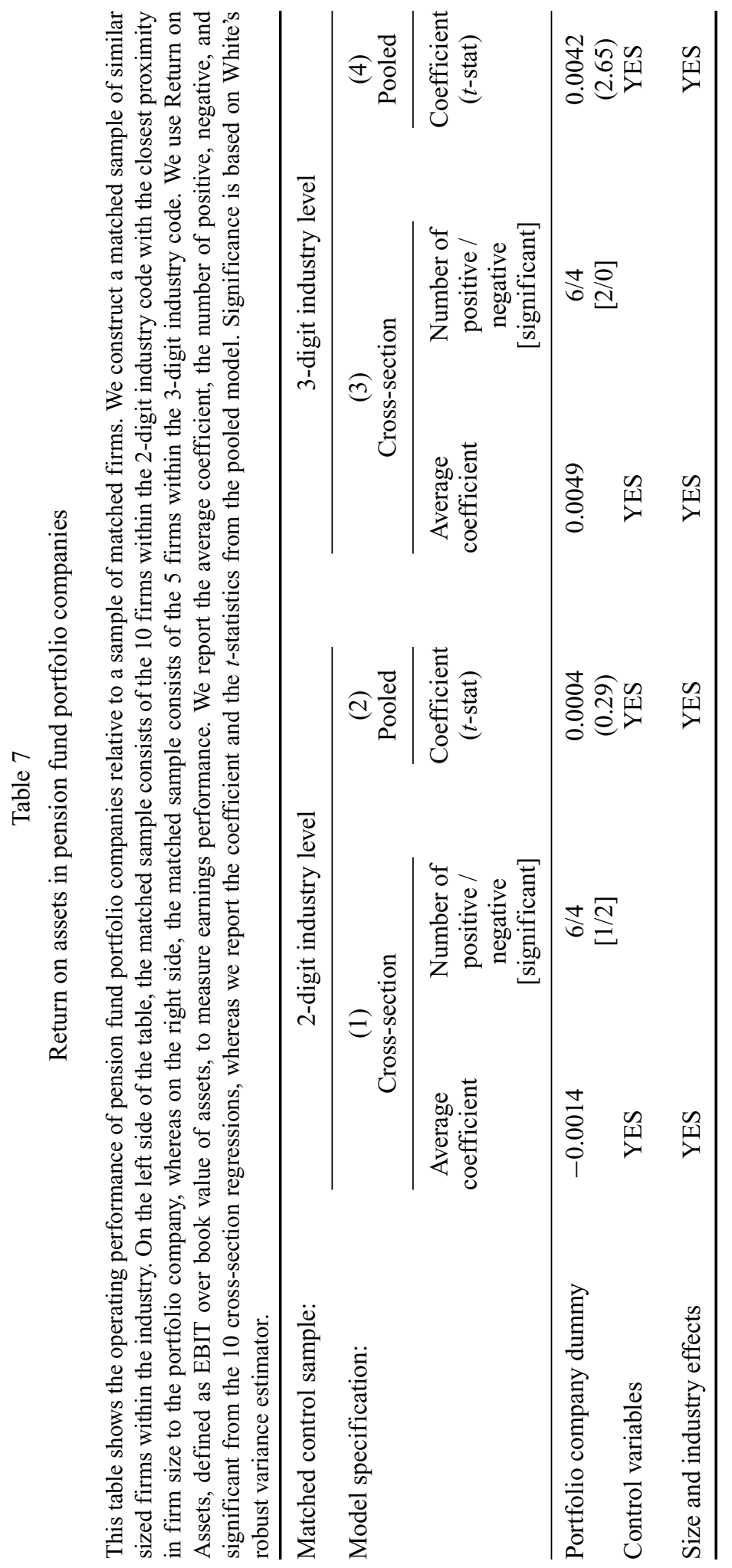


In the left panel of Table 7, where the matching procedure is based on two-digit industry codes, the coefficient on pension funds' portfolio companies have mixed signs and significance: in 6 (4) out of 10 regressions, the coefficient is positive (negative), but only significant at the 5 percent level in 2 (1) cases. Consistently, the average coefficient across the ten yearly regressions is close to zero. This is confirmed in the pooled model, where the coefficient is positive, but insignificant. These results are robust with respect to the level of industry matching, since we find similar results when we match within three-digit industry codes. On average, pension fund portfolio companies perform no differently than a matched sample of similar firms.

Overall, we find no significant difference in the earnings performance of pension fund portfolio companies. Given the average performance, the disappointing return cannot be explained by poor selection of investments from the population of firms. The poor return has to be caused by low capital gains. Because value is composed by current performance plus expected performance, the low return might be caused by high initial expectations about future performance that did not materialize. Thus, low returns most likely result from initial over-optimism or misperceived risk (or both). In both cases, pension funds will initially misprice the portfolio companies, and subsequently experience low abnormal returns. Thus, the evidence points to initial over-optimism and misperceived risk as important sources of the disappointing returns. As pension funds are perceived to be professional investors, our findings might also indicate that the much cited non-pecuniary benefits do not stand alone in explaining the private equity premium puzzle for entrepreneurs and entrepreneurial households. Over-optimism and misperceived risk are likely to contribute as well.

\subsection{Other explanations related to pensions funds}

In this section, we discuss a number of other explanations for why pension funds might invest in private firms despite poor returns.

Pension funds manage large portfolios of assets; it might therefore be sensible to hold a small fraction of private equity if the return is sufficiently uncorrelated with the return on other assets. In fact, standard portfolio theory predicts that investors should hold positive portfolios of all assets with positive risk adjusted returns. For instance, using U.S. data, Hwang, Quigley, and Woodward (2005) show that a mean-variance investor would want to invest a positive fraction in private equity. However, using the same data as Hwang, Quigley, and Woodward (2005), Woodward (2004) shows that private equity appears to have positive risk adjusted returns because the correlations between the return to private equity and other assets are significantly negatively biased by the stale pricing problem. In a similar vein, Moskowitz and Vissing-Jørgensen (2002) show that private equity does not appear to have particularly attractive hedging properties.

In a study of relationship banking in venture capital, Hellmann, Lindsey, and Puri (2004) suggest that banks might sacrifice returns in order to obtain future banking income from the portfolio firms. As a case in point, pension funds might diverge from maximizing the return to obtain future pension customers. However, this alternative explanation receives little support since the pension funds' portfolio firms have, on average, few employees. The average (median) number of employees in portfolio firms in 2004 is 144 (12). As the average private equity portfolio consists of few firms (see Table 2), the prospects for generating future pension fees are not large enough to cover the large gap in returns. 
Another possible explanation is that pension funds might be committed to the development of the local economy and, therefore, invest in private firms to stimulate growth and innovation. Historically, pension funds in the U.S. have been encouraged by in-state investment programs to invest directly in local private firms and fund local venture capitalists. ${ }^{19}$ In Europe, pension funds have historically been influenced by unions, which suggests that investment decisions might be influenced by political preferences. Political investments to sustain employment in unprofitable industries might have induced pension funds to invest in private firms. Again, it is hard to argue that this political preference should affect investments in private firms significantly differently than it affects investments in public firms. Further, as these politically motivated investments tend to attract significant media attention, there seem to be too few examples to explain the large underperformance. Nevertheless, to quantify the influence of political investments, we use another novel feature of our data: our sample of pension funds consists of two types, one managed by labor market parties (unions and employers' organizations) and one managed by financial intermediaries. Where politics pervade investment decisions in pension funds managed by unions and employers' organizations, we should expect a lower return to private equity for this group, if political motives take precedence.

Panel A in Table 8 shows the return to private firms for pension funds managed by labor market parties and those managed by financial intermediaries, respectively. On average, pension funds managed by labor market parties realized an annual return of 8.5 percent, as compared to 7.7 for funds managed by financial intermediaries. The difference of 0.7 percent is highly insignificant.

To further examine the impact of politically motivated investments, we examine election rules in the pension fund bylaws that grant board seats to political organizations (defined as unions and associations of local governments). ${ }^{20}$ If political organizations are granted the right to appoint board members, they can indirectly influence pension fund investment policy. In particular, we are interested in board seats granted to unions and associations of local governments as they appoint their leaders and (local) politicians, respectively. By measuring the number of board seats granted to political organizations, we thereby obtain a measure of the political influence on pension fund investment policy.

Table 8 also shows the return to private firms for pension funds as a function of the degree of political influence on the boards. We use two measures: in Panel B we divide the pension funds based on whether at least 1 board seat is granted to a political organization; in Panel $\mathrm{C}$ we divide them based on whether the majority of board seats are granted to political organizations. Using both measures, we find no significant difference in the return of politically influenced boards. Thus, politically motivated investments do not seem to explain why pension funds invest in private firms despite the poor return. Otherwise, we should have found a significantly lower return to politically influenced pension funds' private equity investments.

To conclude, we acknowledge that in the case where all pension funds' investments in private firms are politically motivated, our test would fail to recognize this. Rather, we

\footnotetext{
${ }^{19}$ Consistently, Lerner, Schoar, and Wongsunwai (2007) find evidence that suggest that public pension funds and public universities in the United States face politically motivated pressures or constraints to invest in their local areas with unfavorable effects on performance.

${ }^{20}$ As employers in a wide range of professions (e.g., education, child care, health care, etc.), local governments are actively involved in pension funds managed by labor market parties.
} 


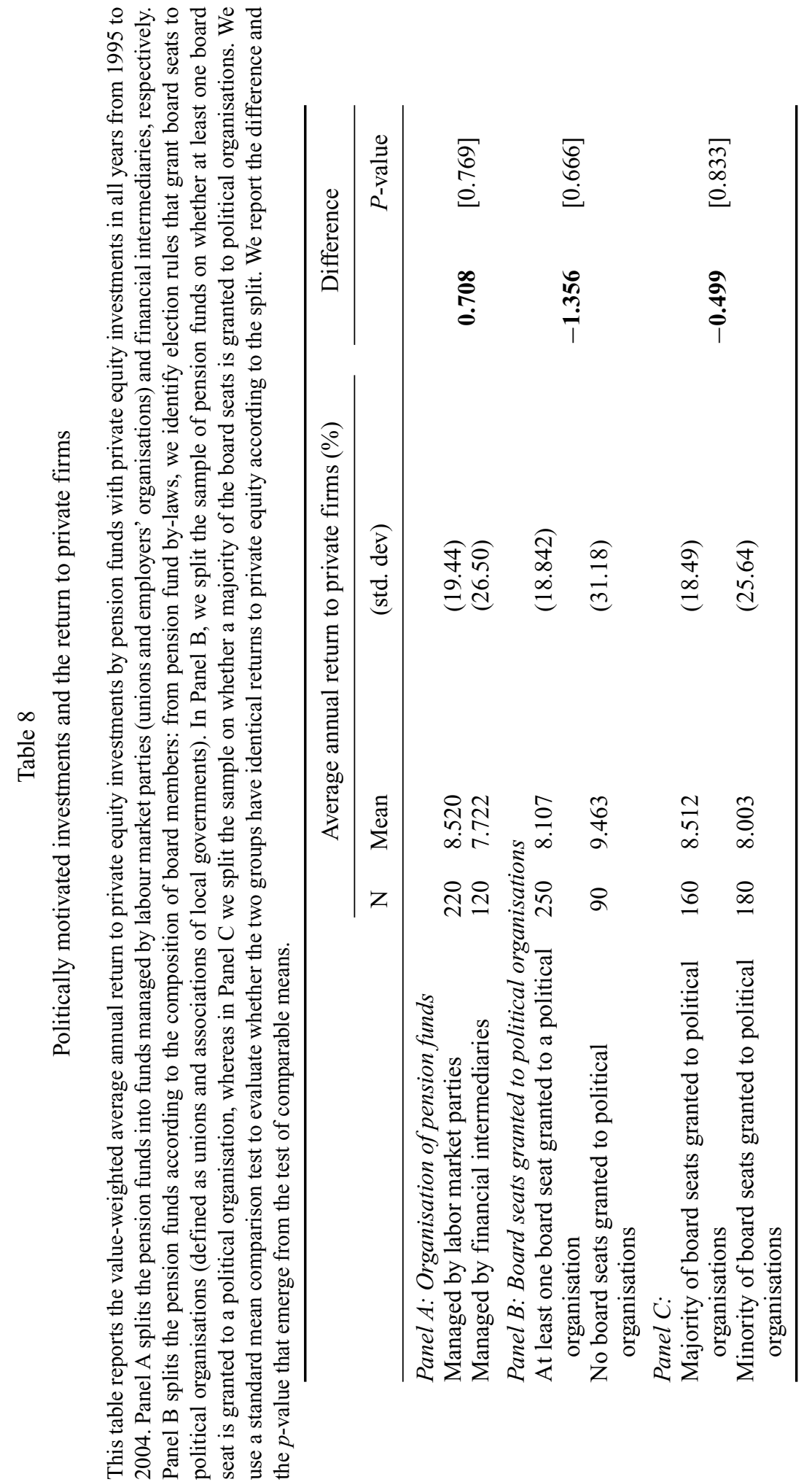


used the within-sample variation to show that the return to pension funds' private equity investments is unrelated to the organization of the pension fund and to the number of board seats granted to political organizations. We thereby find no evidence to suggest that political preferences can explain why pension funds accept the poor risk-return tradeoff.

\section{Conclusion}

Prior studies of return to private equity investments show that the return to private equity funds net of fees is disappointing. This paper makes use of a novel dataset to examine whether, alternatively, pension funds can get private equity exposure by investing directly in private firms. We show that Danish pension funds' direct investments in private firms has dramatically underperformed: our most conservative risk-adjusted estimate shows that the return to direct investments in private firms lags public equity by 3.9 percentage points per annum. To the best of our knowledge, this is the first estimate of the return to private firms by investors without an active management role.

An additional novel feature of our data is that we have access to the portfolio companies that have generated the returns and to the entire population of privately held firms. This allows us to evaluate potential explanations for the realized return. We find that most of the potential explanations discussed in prior literature cannot explain the large gap in the pension funds' private equity returns. We disentangle the source of this underperformance to show that it is driven by missing capital gains that result, presumably, from over-optimism and misperceived risk. As pension funds are perceived to be professional investors, the importance of over-optimism and misperceived risk in explaining poor realized returns to investments in private firms is likely to extend to entrepreneurs and entrepreneurial households as well. Overall, these findings suggest that the private equity premium puzzle raised by Moskowitz and Vissing-Jørgensen (2002) extends to professional investors with diversified portfolios.

\section{References}

Cochrane, J., The risk and return of venture capital, Journal of Financial Economics, Vol. 75, 2005, pp. $3-52$.

Cumming, D. and Johan, S., Regulatory harmonization and the development of private equity markets, Journal of Banking and Finance, Vol. 31, 2007, pp. 3218-3250.

Cumming, D. and Waltz, U., Private equity return and disclosure around the world, Journal of International Business Studies, Vol. 41, 2010, pp. 727-754.

Daniel, K., Grinblatt, M., Titman, S. and Wermers, R., Measuring mutual fund performance with characteristics-based benchmarks, Journal of Finance, Vol. 52, 1997, pp. 1035-1058.

Del Guercio, D., The distorting effect of the prudent-man laws on institutional equity investments, Journal of Financial Economics, Vol. 40, 1996, pp. 31-62.

Denis, D. J., Entrepreneurial finance: An overview of the issues and evidence, Journal of Corporate Finance, Vol. 10, 2004, pp. 301-326.

Dreissen, J., Lin, T.-C. and Phalippou, L., A new method to estimate risk and return from non-traded assets from cash flows: The case of private equity funds, Working paper (National Bureau of Economic Researchs, 2009).

Fama, E. and French, K., Common risk factors in the return on stocks and bonds, Journal of Financial Economics, Vol. 33, 1993, pp. 3-56.

Fenn, G., Liang, N. and Prowse, S. 1997. The private equity market: An overview, Financial Markets, Institutions, and Instruments, Vol. 6, 1997, pp. 1-106. 
Gompers, P. A. and Lerner, J., Risk and reward in private equity investments: The challenge of performance assessment, The Journal of Private Equity, Winter 1997, pp. 5-12.

Gompers, P. A. and Lerner, J., The venture capital revolution, Journal of Economic Perspectives, Vol. 15,2001 , pp. 145-168.

Gompers, P. A. and Metrick, A., Institutional investors and equity prices, Quarterly Journal of Economics, Vol. 116, 2001, pp. 229-259.

Hamilton, B. H., Does entrepreneurship pay? An empirical analysis of the return to self-employment, Journal of Political Economy, Vol. 108, 2000, pp. 1163-1198.

Hellmann, T., Lindsey, L. and Puri, M., Building relationships early: Banks in venture capital, The Review of Financial Studies, Vol. 21, 2004, pp. 513-541.

Hwang, M., Quigley, J. M. and Woodward, S. E., An index for venture capital, 1987-2003. B.E. Journals of Analysis and Policy, Vol. 4, 2005, Article 13.

Jones, C. and Rhodes-Kropf, M., The price of diversifiable risk in venture capital and private equity, Working paper (Columbia University, 2003).

Kaplan, S. and Schoar, A., Private equity performance: Returns, persistence, and capital flows. Journal of Finance, Vol. 60, 2005, pp. 1791-1823.

Korteweg, A. and Sørensen, M., Risk and return characteristics of venture capital-backed entrepreneurial companies, Review of Financial Studies, forthcoming.

Risk and Return Characteristics of Venture Capital-Backed Entrepreneurial Companies" (with Morten Sørensen), forthcoming, Review of Financial Studies.

Lerner, J., Schoar, A. and Wongsunwai, W., Smart institutions, foolish choices?: The limited partner performance puzzle, Journal of Finance, Vol. 62, 2007, pp. 1-54.

Ljungqvist, A. and Richardson, M., The cash flow, return, and risk characteristics of private equity, Working paper (National Bureau of Economic Research, 2003).

Martin, J. D. and Petty, W., An analysis of the performance of publicly traded venture capital companies, Journal of Financial and Quantitative Analysis, Vol. 18, 1983, pp. 401-410.

Moskowitz, T. and Vissing-Jørgensen, A., The returns to entrepreneurial investment: A private equity premium puzzle?, American Economic Review, Vol. 92, 2002, pp. 745-778.

Nielsen, K. M., Institutional investors and private equity, Review of Finance, Vol. 12, 2008, pp. 185-219.

Nielsen, K. M., Direct investments in private firms by institutional investors: Issues and evidence, in D. Cumming, eds, Handbook on Entrepreneurial Finance (Oxford: Oxford University Press, forthcoming)

Phalippou, L. and Gottschalg, O., The performance of private equity funds, forthcoming, Review of Financial Studies, Vol. 22, 2009, pp. 1747-1776.

Peng, L., Building a venture capital index, Working paper (Yale University, 2003).

Quigley, J. M. and Woodward, S. E., An index for venture capital, Working paper (University of California at Berkeley, 2003).

Scholes, M. and Williams, J. T., Estimating betas from non-synchronous data, Journal of Financial Economics, Vol. 5, 1977, 309-327.

Watson, Wyatt, Pensions \& Investments-Watson Wyatt Global 300 survey, London, United Kingdom, 2006.

Woodward, S. E., Measuring risk and performance for private equity, Working paper (Sand Hill Econometrics, 2004).

Woodward, S.E. and Hall, R.E., Benchmarking the returns to venture capital, Working paper (Sand Hill Econometrics, 2003). 